ISSN: 2302-8556

E-Jurnal Akuntansi Universitas Udayana

Vol.24.3.September (2018):1938-1963

DOI: https://doi.org/10.24843/EJA.2018.v24.i03.p11

\title{
Pengalaman Auditor, Tekanan Batas Waktu Audit dan Locus Of Control Internal Pada Skeptisisme Profesional Auditor
}

\author{
Nyoman Ayu Oktaviani ${ }^{1}$ \\ Made Yenni Latrini ${ }^{2}$
}

\author{
${ }^{1}$ Fakultas Ekonomi dan Bisnis Universitas Udayana (Unud), Bali, Indonesia \\ email: ayuoktaviani_shandy@yahoo.com/tlp. 083129041130 \\ ${ }^{2}$ Fakultas Ekonomi dan Bisnis Universitas Udayana (Unud), Bali, Indonesia
}

\begin{abstract}
ABSTRAK
Penelitian ini bertujuan untuk menguji pengaruh pengalaman auditor, tekanan batas waktu audit, dan locus of control internal pada skeptisisme profesional auditor. Penelitian ini dilakukan pada Kantor Akuntan Publik di Bali. Sampel yang digunakan sebanyak 44 auditor dengan menggunakan metode nonprobability sampling dan teknik purposive sampling. Data dikumpulkan dengan menggunakan metode kuesioner. Teknik analisis data yang digunakan adalah Analisis Regresi Linear Berganda. Hasil pengujian hipotesis menunjukkan bahwa semakin tinggi pengalaman auditor dalam melaksanakan tugas auditnya, maka skeptisisme profesional auditor semakin meningkat. Semakin optimal tekanan batas waktu audit yang diterima oleh auditor, maka akan mendukung auditor untuk meningkatkan sikap skeptisisme profesionalnya. Semakin baik locus of control internal auditor, maka semakin tinggi pula skeptisisme profesional yang dimiliki oleh auditor.

Kata kunci: Pengalaman auditor, tekanan batas waktu audit, locus of control internal auditor, skeptisisme profesional auditor
\end{abstract}

\begin{abstract}
This study aims to examine the effect of auditor experience, audit time deadline pressure, and internal locus of control on professional skepticism of auditors. This research was conducted at Public Accounting Firm in Bali. The samples used were 44 auditors using nonprobability sampling method and purposive sampling technique. Data were collected by using questionnaire method. Data analysis technique used is Multiple Linear Regression Analysis. The results of hypothesis testing show that the higher the auditor's experience in carrying out its audit duties, the auditor's professional skepticism is increasing. The more optimal the audit time deadline pressure is received by the auditor, it will support the auditor to improve his professional skepticism. The better the locus of control of the internal auditor, the higher the professional skepticism the auditor has.

Keywords: Auditor experience, audit time deadline pressure, locus of control internal auditor, professional skepticism auditor
\end{abstract}

\section{PENDAHULUAN}

Informasi keuangan yang disajikan suatu perusahaan dalam bentuk laporan keuangan sangat dibutuhkan bagi para pelaku kepentingan usaha dalam pengambilan 
keputusan. Oleh karena itu, manajemen perusahaan membutuhkan jasa pihak ketiga agar informasi keuangan yang disajikan bisa dipercaya, sedangkan pihak diluar perusahaan membutuhkan jasa pihak ketiga untuk mendapatkan kepastian bahwa laporan keuangan yang disajikan oleh manajemen perusahaan bisa dipertanggung jawabkan sebagai dasar keputusan yang diambil (Mulyadi, 2008). Dengan demikian hasil audit laporan keuangan harus dilakukan oleh pihak independen, yang disebut sebagai auditor independen atau akuntan publik.

Auditor memiliki tanggung jawab pada pelaksanaan audit serta mendapatkan dan mengevaluasi bukti mengenai asersi tentang kegiatan-kegiatan dan kejadiankejadian ekonomi untuk memastikan tingkat keterkaitan antara asersi tersebut dengan kriteria yang telah ditetapkan, dan juga dapat menyatakan hasilnya kepada pihakpihak yang berkepentiingan. Dari keperluan inilah diperlukan pekerjaan auditor karena opini auditor tentang laporan keuangan perusahaan dapat mempengaruhi keputusan para pemegang saham.

Menjalankan penugasan audit dan mampu menghasilkan kualitas audit yang baik maka, auditor harus dapat memiliki sikap skeptis atas bukti-bukti yang diberikan oleh kliennya. Skeptisime profesional merupakan sikap auditor yang memiliki keraguan dan selalu mempertanyakan segala sesuatu dan megevaluasii secara detail terhadap bukti-bukti audit serta keputusan audit yang diambil berlandaskan keahlian auditing yang ia miliki. Sikap skeptis ini mengaharuskan auditor bersikap dan bertindak dengan hati-hati, meyeluruh dan tepat waktu sesuai dengan persyaratan penugasan (SPAP Seksi 230 paragraf 06, 2011). Skeptisisme profesional auditor 
ISSN: 2302-8556

E-Jurnal Akuntansi Universitas Udayana Vol.24.3.September (2018):1938-1963

diperlukan untuk dapat meminimalisasi adanya kesalahan yang dilakukan auditor saat melakukan pemeriksaan atas laporan keuangan.

Beasley et al. (2001) yang didasarkan pada AAERs (Accounting and Auditing Releases) dari SEC (Securities and Exchange Commissions) menyatakan adanya gagalnya auditor mendeteksi kecurangan disebabkan rendahnya tingkat skeptisime profesional audit. Pada penelitian iini, 45 kasus kecurangan laporan keuangan, diantaranya $60 \%$ disebabkan auditor yang kurang menerapkan skeptisisme profesionalnya dan dari audit defisiensi yang paling sering terjadi hal ini menjadi urutan ketiga. Tingkat skeptisisme profesional yang rendah penyebab utama gagalnya mendeteksi kecurangan (Noviyanti, 2008). Uraian diatas menyatakan sikap skeptisime profesional seorang auditor penting pada saat mengaudit terutama dalam mendeteksi kemungkinan adanya kecurangan dan ketepatan pemberian opini yang diberikannya. Masalahnya sekarang adalah bagaimana caranya agar setiap auditor senantiasa dapat memelihara dan meningkatkan skeptisisme profesionalnya.

Skandal kasus yang terjadi didunia bisnis menyangkut gagalnya auditor mengetahui adanya kecurangan terbukti bahwa beberapa kasus skandal keuangan yang melibatkan akuntan publik seperti yang terjadi pada Olynpus Corp. Kasusunya terungkap pada akhir tahun 2011 lalu yang merupakan perusahaan berasal dari Jepang yaitu berupa peralatan kesehatan dan produsen kamera dimana menyembunyikan kerugiannya dengan beranggapan sebagai aset sejak tahun 1990-an. Mencuatnya kasus ini setelah dewan Olympus memecat CEO, Michael C.Woodford yang baru menjabat selama enam bulan, dikarenakan ia terus mendesak harus mengadakan 
penyelidikan internal terkait kecurigaan biaya advisory. Setelah dipecatnya dia memperlihatkan dokumen yang terdapat besarnya biaya advisory yang telah dibayar Olympus untuk mengakuisisi perusahaan alat kesehatan asal Inggris, yaitu Gyrus pada tahun 2008. Perusahaan ini telah bergantian diaudit oleh KAP yang tergolong big five yaitu Arthur Andersen, KPMG dan Ernest \& Young. Tetapi hasil audit yang dihasilkan menyatakan terjadi gagalnya mendeteksi dan juga mengungkapkan kecurangan laporan keuangan.

(indonesiafinancetoday.com dan finance.detik.com.2011).

Berdasarkan skandal diatas selain Arthur Andersen, bahwa KPMG dan Ernst\&Young tidak juga kompeten mengaudit perusahaan tersebut, disebabkan gagalnya auditor mendeteksi dan juga mengungkapkan kecurangan laporan keuangan Olympus Corp. Hal ini disebabkan cukup rendahnya independensi, pengalaman, keahlian dan minimnya sikap skeptisisme profesional auditor dalam mengaudit laporan keuangan. Sehingga dampaknya akan mempengaruhi persepsi orang-orang yang berkepentingan yang menggunakan laporan keuangan dengan kualitas audit yang dihasilkan. Oleh karena itu, penulis merasa perlu mengkaji dan meneliti bagaimana skeptisisme profesional pada auditor yang bekerja di Kantor Akuntan Publik khususnya auditor pada KAP di Provinsi Bali dalam kaitan pelaksanaan pemeriksaan laporan keuangan perusahaan, dalam rangka mendeteksi kemungkinan adanya kecurangan dan ketepatan pemberian opini yang diberikannya.

Arens (2012) menyatakan adanya Standar Umum pada Standar Profesional Akuntan Publik bahwa auditor harus memiliki pengalaman kerja yang cukup terhadap 
ISSN: 2302-8556

profesi yang ia tekuni, dan juga dituntut untuk memenuhi kualifikasi teknis dan berpengalaman dalam bidang industri yang digeluti. Pengaruh pengalaman menjadi penting mengingat dalam pelaksanaan audit atas laporan keuangan yang dilakukan, auditor diharuskan menggunakan kemahiran profesionalnya dengan cermat dan seksama. Untuk memenuhi kebutuhan tersebut KAP membuat perencanaan audit yaitu dengan dibentuknya anggota tim perikatan atau tim audit yang terpilih kemampuan dan kompetensinya untuk merespon segala risiko yang dapat ditangani, dan penugasan pekerjaan yang tepat kepada masing-masing auditor. Dalam penyusunan tim pemeriksaan diharpkaan bisa memperhatikan faktor pengalaman masing-masing auditor sehingga pelaksanaan dapat berjalan efektif.

Selain pengalaman auditor faktor yang digunakan penelitian ini adalah tekanan batas waktu audit yang mempengaruhi skeptisisme profesional auditor, mengingat adanya perundang-undangan atas batas waktu penyampaian laporan audit dari pihak ketiga seperti regulator perusahaan yang terdaftar di BEI (Bursa Efek Indonesia) yang publikasi laporan keuangannya diatur ketat oleh Bapepam. Dalam Undang-Undang No.8 tahun 1995 tentang Pasar Modal dan selannjutnya diatur dalam Keputusan Ketua Bapepam Nomor Kep-80/PM/1996 dinyatakan selambatlambatnya pada akhir bulan keempat (120 hari) setelah tanggal laporan keuangan perusahaan, emiten dan perusahaan publik wajib disampaikannya laporan keuangan tahunannya yang sudah diaudit oleh akuntan independen. Selanjutnya BAPEPAM telah mengeluarkan peraturan yang diperketat lagi yaitu Keputusan Ketua Badan Pengawas Pasar Modal Nomor Kep-36/PM/2003 tentang Kewajiban Penyampaian 
Laporan Berkala, yaitu dikeluarkannya Peraturan Bapepam Nomor X.K.2 yang menyatakan selambat-lambatnya pada akhir bulan ketiga (31 Maret) setelah tanggal laporan keuangan, bahwa wajib laporan keuangan tahunan yang telah disertai dengan adanya pendapat yang lazim pada laporan keuangan tersebut. Sehingga auditor menghadapi tekanan untuk bisa meyelesaikan pekerjaan auditnya tepat waktu karena jika melampaui batas waktu tersebut, maka auditor independen dianggap memiliki kinerja buruk. Adanya ketentuan tersebut diakhir bulan ketiga setelah tanggal laporan keuangan harus disampaikan kepada Bapepam merupakan target waktu yang dicapai dengan usaha-usaha maksimal dari para auditor KAP.

Robertson (2007) menyatakan bahwa adanya time deadline pressure tidak mempengaruhi auditor dalam memberikan keputusan terhadap pelaporan. Yanti (2012) menyatakan bahwa tekanan batas waktu audit berpengaruh positif pada skeptisisme profesional auditor. Adanya batasan waktu penyelesaian audit diharapkan menjadi stimulus sehingga diharapkan auditor merespon tekanan batas waktu audit dengan baik dan termotivasi agar memiliki sikap skeptis pada bukti audit yang ia periksa. Faktor locus of control internal juga penting untuk dipertimbangkan sebagai salah satu faktor yang mempengaruhi skeptisisme profesional auditor. Individu yang memiliki locus of control internal akan memandang dunia bahwa perilakunya turut berperan di dalamnya. Individu yang mempunyai locus of control internal diidentifikasikan lebih banyak menyandarkan harapannya pada diri sendiri dibanding hanya situasi yang menguntungkan. Robbin dan Judge (2008) menyatakan locus of control internal sebagai tingkat dimana individu yakin bahwa ia adalah penentu 
ISSN: 2302-8556

E-Jurnal Akuntansi Universitas Udayana Vol.24.3.September (2018):1938-1963

nasibnya sendiri. Semakin baik locus of control internal auditor, maka semakin tinggi pula skeptisisme profesional yang ditunjukkan oleh auditor (Alfa, 2013).

Pengaruh locus of control internal menjadi penting karena dalam pengambilan keputusan seseorang akan dipengaruhi oleh sikap seseorang dan sikap seseorang akan dipengaruhi oleh kepribadian seseorang dan individu dengan locus of control internal yakin bahwa ia adalah penentu nasibnya sendiri. Mengingat ancaman auditor dengan lokus of control internal yang timbul ketika adanya hubungan bisnis yang dekat dengan klien, hubungan keluarga atau hubungan pribadi dengan klien, dan adanya keterkaitan yang cukup lama antar auditor senior KAP dengan klien perusahaan. Standar Profesional Akuntan Publik (SPAP) Seksi 290 dalam Jusup (2014), menyebutkan bahwa setiap auditor harus memiliki independensi dalam pemikiran dan independensi dalam penampilan. Jika auditor memiliki locus of control internal yang baik maka dia yakin untuk memiliki skeptisisme profesionalnya dengan teguh dan dia yakin kualitas audit yang dihasilkannya berkualitas.

Pengalaman merupakan faktor personal yang dapat membentuk sikap seseorang (Siegel dan Marconi, 1989). Pengalaman yang dimaksudkaan peneliti adalah pengalaman auditor dalam mengaudit laporan keuangan dari lamanya waktu serta banyaknya penugasan. Penelitian Shaub dan Lawrence (1996) menyatakan bahwa semakin banyak pengalaman auditor khususnya lamanya bekerja sebagai auditor semakin tinggi pula tingkat skeptisisme profesional auditor.

Silalahi (2013) menyatakan auditor yang berpengalaman akan lebih selektifitas pada informasi yang relevan, sehingga seorang auditor mampu 
dipengaruhi untuk memiliki sikap skeptisisme profesional auditor, hal ini didukung oleh Tubbs (1992) menyatakan jika auditor memiliki pengalaman yang lebih maka dia akan sadar mengenai adanya kekeliruan yang tidak lazim. Penelitian Oktaviani (2015) menyatakan semakin berpengalaman seorang auditor maka akan semakin baik sikap skeptisisme profesional auditornya. Penelitian Suraida (2005) menunjukkan bahwa auditor yang berpengalaman bersikap lebih skeptis. Attamimi (2015) menyatakan pengalaman menunjukan hubungan positif dan berpengaruh signifikan terhadap skeptisme profesional auditor.

$\mathrm{H}_{1}$ : Pengalaman auditor berpengaruh positif pada skeptisisme profesional auditor.

Tekanan batas waktu audit dalam penelitian ini diduga memiliki pengaruh terhadap skeptisisme profesional auditor dalam dilakukannya pemeriksaan. Auditor bertanggung jawab dalam melaksanakan pemeriksaan sesuai standar. Adanya batasan waktu penyelesaian audit diharapkan menjadi stimulus sehingga diharapkan auditor merespon tekanan batas waktu audit dengan baik dan termotivasi agar memiliki sikap skeptis pada bukti audit yang diperiksanya.

Penelitian Sweeney (2003) yang menemukan bahwa tekanan waktu dapat berdampak terhadap sikap (attitude) seseorang. Sweeney (2003) menyatakan bahwa time deadline pressure berpengaruh terhadap sikap auditor dalam pelaksanaan pemeriksaan. Penelitian ini menemukan bahwa tekanan batas waktu yang diterima auditor secara optimal bisa memberikan pengaruh positif kepada auditor untuk memusatkan dirinya pada penyelesaian pekerjaan, memberikan hubungan yang lebih efektif dengan klien, memberikan perhatian lebih pada informasi-informasi yang 
ISSN: 2302-8556

E-Jurnal Akuntansi Universitas Udayana Vol.24.3.September (2018):1938-1963

relevan, menghilangkan pekerjaan yang tidak perlu dan berkomunikasi secara lebih baik dengan atasan. Penelitian Yanti (2012) menyatakan bahwa tekanan batas waktu audit berpengaruh positif signifikan terhadap skeptisisme professional auditor. Penelitian ini juga didukung oleh Dezort (2002) dan Syahmina (2016).

$\mathrm{H}_{2}$ : Tekanan batas waktu audit berpengaruh positif pada skeptisisme profesional auditor.

Seseorang yang mempunyai locus of control internalakan cenderung lebih sukses berkarier dari pada eksternal, dia cenderung memiliki tingginya level kerja yang diperoleh, cepat mendapatkaan promosi dan pendapatan yang dia peroleh akan mudah dia dapatkan. Sebagai tambahan, internal dilaporkan kepuasan yang dia miliki lebih tinggi dengan pekerjannya dan terlihat lebih mampu mengendalikan stress daripada eksternal (Baron \&Greenberg,1990 dalam Kusnadi, 2015).

Auditor locus of control internal kecil kemungkinannya mengambil keputusan yang tidak benar. Dalam hal ini, besar kemungkinannya ia akan mengambil keputusan yang lebih independen (Retnowati, 2009:20). Robbin dan Judge (2008) mendefinisikan locus of control internal sebagai tingkat dimana ia yakin bahwa dapat menentukan nasibnya sendiri. Jadi dia akan memegang penuh kendali atas apa kejadian, aktifitas yang dilakukan, serta hasil kinerjanya.

Penelitian Alfa (2013) menyatakan locus of control internal berpengaruh positif terhadap skeptisisme profesional auditor. Jika seseorang auditor lebih memiliki locus of control internal, maka dia yakin dengan kemampuan dirinya itu dapat menyelesaikan suatu permasalahan, bersikap hati-hati dan auditor tersebut 
akan mengevaluasi bukti audit dengan detil didukung dengan kemahiran profesionalnya yang cermat dan seksama Clark (2011).

$\mathrm{H}_{3}$ : Locus of control internal berpengaruh positif pada skeptisisme profesional auditor.

\section{METODE PENELITIAN}

Penelitian yang dilakukan oleh peneliti menggunakan pendekatan kuantitatif. Metode penelitian yang digunakan berbentuk penelitian asosiatif dengan tipe kausalitas. Secara skematis penelitian ini seperti berikut.

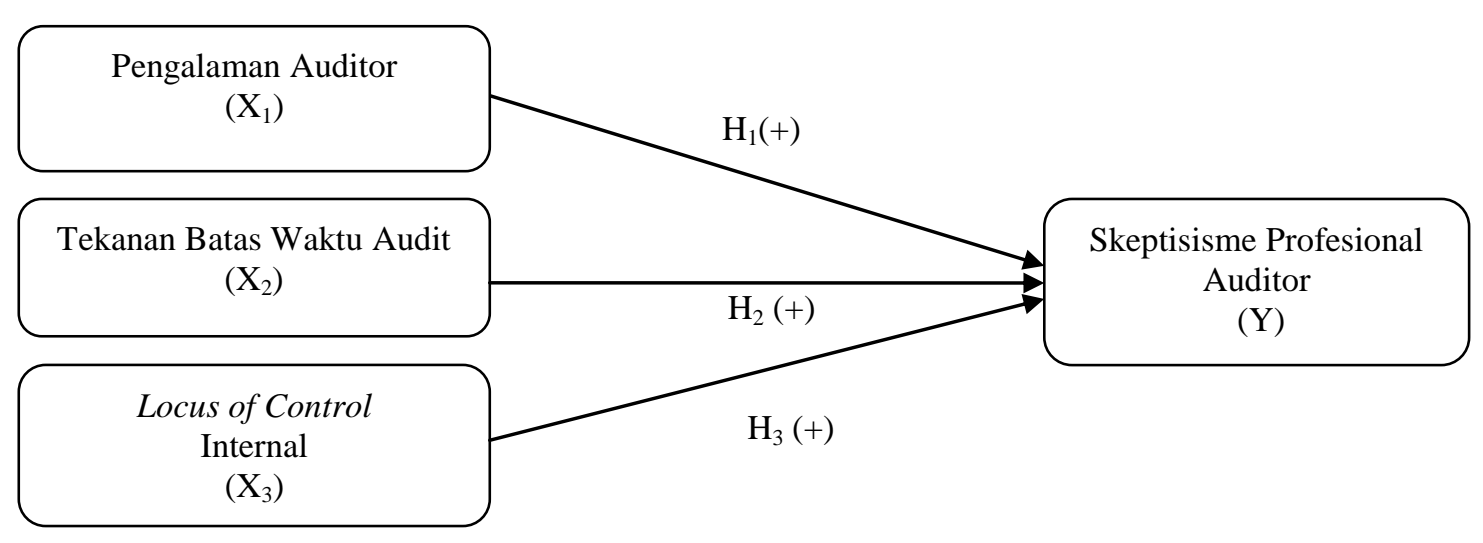

\section{Gambar 1. Kerangka Konseptual Penelitian}

Obyek penelitian ini adalah skeptisisme profesional auditor yang dipengaruhi oleh pengalaman auditor, tekanan batas waktu audit, locus of control internal pada auditor KAP di Bali. Lokasi dari penelitian ini yakni KAP yang berada di Bali dan terdaftar dalam Direktorat Kantor Akuntan Publik Indonesia Tahun 2017. Jumlah KAP yang terdaftar pada Direktori Institut Akuntan Publik Indonesia (IAPI) tahun 2017 disajikan pada Tabel 1. 
ISSN: 2302-8556

E-Jurnal Akuntansi Universitas Udayana Vol.24.3.September (2018):1938-1963

Tabel 1.

Daftar Nama Kantor Akuntan Publik di Bali, 2017

\begin{tabular}{|c|c|c|}
\hline No & Nama Kantor Akuntan Publik & Alamat Kantor Akuntan Publik \\
\hline 1 & KAP I Wayan Ramantha & $\begin{array}{l}\text { Jl. Rampai No. } 1 \text { A Lantai 3, Denpasar, Bali } 80235 \\
\text { Telp : (0361) } 263643\end{array}$ \\
\hline 2 & KAP Drs. Ida Bagus Djagera & $\begin{array}{l}\text { Jln Hassanuddin no. 1, Denpasar, Bali } 80112 \\
\text { Telp : (0361) 234960, 225138, } 227460\end{array}$ \\
\hline 3 & $\begin{array}{l}\text { KAP Johan Malonda Mustika \& } \\
\text { Rekan (Cab) }\end{array}$ & $\begin{array}{l}\text { Jl. Muding Indah I No. } 5 \text { Kuta Utara, Kerobokan } \\
\text { Denpasar } 80361 \\
\text { Telp : (0361) } 434884\end{array}$ \\
\hline 4 & KAP Drs. Ketut Budiartha, MSi & $\begin{array}{l}\text { Perumahan Padang Pesona Graha Adhi Blok A 6, Jl. } \\
\text { Gunung Agung Denpasar Barat } 80117 \\
\text { Telp : (0361) } 8849168\end{array}$ \\
\hline 5 & KAP Rama Wendra (Cab) & $\begin{array}{l}\text { Pertokoan Sudirman Agung Blok A No. } 43 \text {, Jl. PB } \\
\text { Sudirman, Denpasar, Bali } 80114 \\
\text { Telp : (0361) } 3073333\end{array}$ \\
\hline 6 & 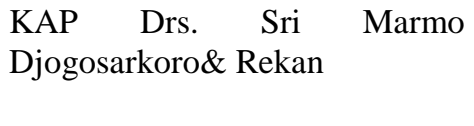 & $\begin{array}{l}\text { Jl. Gunung Muria No.4 Monang-Maning, Denpasar, } \\
\text { Bali } 80119 \\
\text { Telp : (0361) 480032, } 485567\end{array}$ \\
\hline 7 & KAP K. Gunarsa & $\begin{array}{l}\text { Jl. Tukat Banyusari Gang II No.5 Panjer, Denpasar, } \\
\text { Bali } 80225 \\
\text { Telp : (0361) } 225580\end{array}$ \\
\hline 8 & KAP Drs. Wayan Sunasdyana & $\begin{array}{l}\text { Jl. Pura Demak I Gang I.B No. } 8 \text { Teuku Umar Barat, } \\
\text { Pemecutan Kelod Denpasar } 80117 \\
\text { Telp : (0361) 488660, } 488635\end{array}$ \\
\hline 9 & $\begin{array}{l}\text { KAP Drs. Ketut Muliartha R.M. } \\
\text { \& Rekan }\end{array}$ & $\begin{array}{l}\text { Gedung Guna Teknosa Lantai } 2 \text { Jl. Drupadi No. 25, } \\
\text { Renon Denpasar Bali } 80235 \\
\text { Telp: (0361) 248110, } 265227\end{array}$ \\
\hline
\end{tabular}

Sumber: Direktori Institut Akuntan Publik Indonesia (IAPI), 2017

Variabel bebas $(\mathrm{X})$ penelitian ini adalah pengalaman auditor $\left(\mathrm{X}_{1}\right)$, tekanan batas waktu audit $\left(\mathrm{X}_{2}\right)$ dan locus of control internal $\left(\mathrm{X}_{3}\right)$. Pengalaman auditor penelitian ini adalah pengalaman auditor selama melakukan pemeriksaan laporan keuangan yaitu dari segi lamanya waktu maupun banyaknya penugasan yang dilakukan (Suraida, 2005). Variabel ini diukur 6 item pernyataan yang diadopsi dari Oktaviani (2015).

Tekanan batas waktu merupakan tekanan yang tajam dan akut yang disebabkan oleh adanya target khusus untuk penyelesaian tugas (Yanti, 2012). Choo (1995) menjelaskan bahwa tekanan waktu dapat berpengaruh positif dan negatif 
tergantung kepada level tekanan waktu yang dihadapi. Penelitian ini menggunakan indikator tekanan waktu penelitian Sweeney (2003) dan (Yanti, 2012) dengan tujuh atribut operasional tekanan batas waktu yaitu apabila tekanan batas waktu audit optimal. Locus of control internal merupakan sebagai tingkat dimana ia yakin bahwa dapat menentukan nasibnya sendiri (Robbin dan Judge, 2008). Mengukur variabel ini dengan 8 item pernyataan yang diambil dari Christanti (2016).

Variabel terikat $(\mathrm{Y})$ penelitian ini adalah skeptisisme profesional auditor yang merupakan suatu sikap yang mencakup pikiran selalu mempertanyakan dan mengevaluasi secara detail pada bukti audit serta keputusan audit yang diambil berlandaskan keahlian auditing yang ia miliki. Mengukur variabel ini dengan 10 item pernyataan yang diadopsi dari Pramudita (2012).

Data kuantitatif yang digunakaan adalah skor jawaban kuesioner dari masing masing responden. Daftar KAP di Bali yang masih aktif dan terdaftar di direktori IAPI tahun 2017 wilayah Bali merupakan data kualitatif. Hasil jawaban atau kuesioner yang diperoleh dari responden merupakan data primer penelitian ini. Daftar nama KAP di Bali yang terdaftar dalam Direktori IAPI dan jumlah auditor yang bekerja pada masing-masing KAP adalah data sekunder. Populasi penelitian ini yaitu auditor yang bekerja di KAP Provinsi Bali yang terdaftar dalam direktori IAPI tahun 2017.Rincianauditor yang bekerja pada KAP di Bali disajikan dalam tabel 2 sebagai berikut: 
ISSN: 2302-8556

E-Jurnal Akuntansi Universitas Udayana

Vol.24.3.September (2018):1938-1963

\section{Tabel 2.}

\section{Rincian Jumlah Auditor pada KAP di Bali 2017}

\begin{tabular}{llc}
\hline No & \multicolumn{1}{c}{ Nama Kantor Akuntan Publik } & Jumlah Auditor (Orang) \\
\hline $\mathbf{1}$ & KAP I Wayan Ramantha & 10 \\
$\mathbf{2}$ & KAP Drs. Ida Bagus Djagera & - \\
$\mathbf{3}$ & KAP Johan Malonda Mustika \& Rekan (Cab) & 6 \\
$\mathbf{4}$ & KAP Drs. Ketut Budiartha, MSi & 8 \\
$\mathbf{5}$ & KAP Rama Wendra (Cab) & - \\
$\mathbf{6}$ & KAP Drs. Sri Marmo Djogosarkoro\& Rekan & 20 \\
$\mathbf{7}$ & KAP K. Gunarsa & 10 \\
$\mathbf{8}$ & KAP Drs. Wayan Sunasdyana & 10 \\
$\mathbf{9}$ & KAP Drs. Ketut Muliartha R.M. \& Rekan & 12 \\
\hline & Total & 76 \\
\hline
\end{tabular}

Sumber: Data diolah, 2017

Metode nonprobability sampling dengan teknik purposive sampling adalah digunakannya teknik ini untuk penentuan sampel. Teknik purposive sampling yaitu teknik diambilnya sampel berdasarkan beberapa ketentuan yang diinginkan oleh peneliti. Data yang dikumpulkan yaitu berupa kuesioner yang disebar melalui survey. Hasilnya, diukur menggunakan skalaLikert dengan menggunakan skala 5 poin, dengan kriteria sebagai berikut:

\section{Tabel 3.}

Daftar Skala Likert

\begin{tabular}{|c|c|c|}
\hline No & Uraian & Skor \\
\hline 1 & Sangat Tidak Setuju & 1 \\
\hline 2 & Tidak Setuju & 2 \\
\hline 3 & Netral & 3 \\
\hline 4 & Setuju & 4 \\
\hline 5 & Sangat Setuju & 5 \\
\hline
\end{tabular}

Sumber: Data Diolah, 2017

Penelitian ini menganalisis data menggunakan analisis regresi linear berganda yang diproses dengan menggunakan program komputer stastitical package for social science (SPSS). Model regresi penelitian ini dinyatakan sebagai berikut:

$$
Y=a+\beta_{1} X_{1}+\beta_{2} X_{2}+\beta_{3} X_{3}+e
$$


Keterangan :

$\begin{array}{ll}\mathrm{Y} & =\text { Skeptisisme Profesional Auditor } \\ \mathrm{a} & =\text { Konstanta } \\ \beta_{1}-\beta_{3} & =\text { Koefisien Regresi } \\ \mathrm{X}_{1} & =\text { Pengalaman Auditor } \\ \mathrm{X}_{2} & =\text { Tekanan Batas Waktu Audit } \\ \mathrm{X}_{3} & =\text { Locus Of Control Internal } \\ \mathrm{e} & =\text { Standar eror }\end{array}$

\section{HASIL DAN PEMBAHASAN}

Cronbach's alpha adalah teknik yang digunakan menguji reliabilitas. Butir pernyataan atau pertanyaan pada instrument penelitian ini dapat dinyatakan reliabel atau bisa diandalkan apabila Cronbach Alpha variabel $\geq 0,6$. Reliabilitas penelitian ini dapat dilihat pada Tabel 4.

Tabel 4.

Hasil Uji Reliabilitas Instrumen Penelitian

\begin{tabular}{llcl}
\hline No & \multicolumn{1}{c}{ Variabel } & $\begin{array}{c}\text { Cronbach's } \\
\text { Alpha }\end{array}$ & Keterangan \\
\hline 1 & Pengalaman Auditor (X1) & 0,946 & Reliabel \\
2 & Tekanan Batas Waktu Audit (X2) & 0,947 & Reliabel \\
3 & Locus Of Control Internal(X3) & 0,948 & Reliabel \\
4 & Skeptisisme Profesional Auditor (Y) & 0,953 & Reliabel \\
\hline
\end{tabular}

Sumber: Data Diolah, 2017

Cronbach's alpha yang dihasilkan oleh variabel yang digunakan menghasilkan nilai lebih besar dari 0,60 pada tabel 4. Dapat diartikan semua instrument yang digunakan penelitian ini dinyatakan reliabel dan dapat digunakan. Informasi yang terdiri dari atas jumlah pengamatan nilai minimum, nilai maksimum, nilai mean dan standar deviasi atau karateristik variabel-variabel penelitian ini yaitu 
ISSN: 2302-8556

E-Jurnal Akuntansi Universitas Udayana

Vol.24.3.September (2018):1938-1963

terdapat pada statistik deskriptif. Statistik deskriptif penelitian ini dapat dilihat pada Tabel 5.

Tabel 5. Hasil Statistik Deskriptif

\begin{tabular}{llccccc}
\hline No & \multicolumn{1}{c}{ Variabel } & N & Min & Max & Mean & $\begin{array}{c}\text { Std. } \\
\text { Deviation }\end{array}$ \\
\hline 1 & Pengalaman Auditor $\left(\mathrm{X}_{1}\right)$ & 44 & 7,00 & 26,85 & 20,0952 & 6,02350 \\
2 & Tekanan Batas Waktu Audit $\left(\mathrm{X}_{2}\right)$ & 44 & 7,00 & 27,44 & 20,5323 & 6,09449 \\
3 & Locus Of Control Internal $\left(\mathrm{X}_{3}\right)$ & 44 & 8,00 & 30,20 & 22,9895 & 6,76923 \\
4 & Skeptisisme Profesional Auditor $(\mathrm{Y})$ & 44 & 11,95 & 39,11 & 28,9323 & 8,36583 \\
\hline
\end{tabular}
Sumber : Data Diolah, 2017

Nilai minimum yang dimiliki oleh variabel pengalaman auditor dari jumlah skor jawaban responden sebesar 7,00 dan nilai maksimumnya sebesar 26,85, mean sebesar 20,0952 dengan standar deviasi sebesar 6,02350. Ini menunjukkan adanya perbedaan nilai pengalaman auditor yang diteliti terhadap nilai rata-ratanya sebesar 6,02350. Nilai minimum yang dimiliki variabel tekanan batas waktu audit dari jumlah skor jawaban responden sebesar 7,00 dan nilai maksimum sebesar 27,44, nilai mean sebesar 20,5323 dengan standar deviasi sebesar 6,09449. Ini menunjukkan adanya perbedaan nilai tekanan batas waktu audit yang diteliti terhadap nilai rata-ratanya sebesar 6,09449.

Nilai minimum yang dimiliki variabel locus of control internal dari jumlah skor jawaban respondeen adalah 8,00, nilai maksimumnya adalah 30,20, nilai mean adalah 22,9895 dengan standar deviasi sebesar 6,76923. Ini menunjukkan adanya perbedaan nilai locus of control internal yang diteliti terhadap nilai rata-ratanya 
sebesar 6,76923. Nilai minimum dari jumlah skor jawaban reponden untuk variabel skeptisisme profesional auditor sebesar 11,95 nilai maksimumnya sebesar 39,11, nlai mean sebesar 28,9323 dengan standar deviasi sebsar 8,36583. Ini menunjukkan adanya perbedaan nilai skeptisisme profesional auditor yang diteliti terhadap nilai rata-ratanya sebesar 8,36583 .

Model regresi diuji untuk mengetahui apakah model regresi dapat berdistribusi normal atau tidak yaitu dengan melakukan pengujian normalitas. Uji statistik dengan menguji Kolmogorov - Smirnov (K-S) digunakan untuk pengujian normalitas penelitian ini. Hasil dengan menggunakan uji K-S ini menunjukkan unstandardized residumemiliki nilai Kolmogorov Smirnov(K-S) sebesar 0,125 sedangkan nilaiAsymp.Sig (2-tailed) 0,081 lebih besar dari taraf signifikan 0,05. Hasil diatas mengindikasikan bahwa model persamaan regresi tersebut berdistribusi normal.

Hasil uji multikolinearitas penelitian ini bahwa nilai VIF dan tolerance dari variabel pengalaman auditor, tekanan batas waktu audit, dan locus of control internal yang ditunjukkan yaitu hasil nilai tolerance untuk setiap variabel $\geq 0,10$ dan nilai VIF $\leq 10$ yang memiliki arti bebasnya model persamaan regresi dari multikolinearitas. Uji statistik dengan menggunakan uji glejser yang meregresi nilai absolute residual dari model yang diperkirakan pada variabel independen ini digunakan untuk pengujian heteroskedastisitas penelitian ini. Model regresi akan bebas dari masalah heteroskedastisitas apabila nilai tingkat signifikansinya berada di atas 0,05. Hasil uji heteroskedastisitas penelitian ini menunjukkaan nilai signifikansi variabel 
ISSN: 2302-8556

E-Jurnal Akuntansi Universitas Udayana Vol.24.3.September (2018):1938-1963

pengalaman auditor, tekanan batas waktu audit, dan locus of control internal nilainya melebihi 0,05 yang menunjukkan model regresi bebas dari gejala heteroskedastisitas.

Tabel 6.

Hasil Analisis Regresi Linear Berganda

\begin{tabular}{lccc}
\hline \multicolumn{1}{c}{ Keterangan } & Nilai Beta & Signifikansi & Hasil Uji \\
\hline (Constant) & $-4,070$ & 0,123 & - \\
Pengalaman Auditor & 0,640 & 0,000 & $\mathrm{H}_{1}$ diterima \\
Tekanan Batas Waktu Audit & 0,488 & 0,000 & $\mathrm{H}_{2}$ diterima \\
Locus Of Control Internal & 0,440 & 0,000 & $\mathrm{H}_{3}$ diterima \\
& & & \\
\hline$R$ Square $=0,813$ & & & \\
Adjust $R$ Square $=0,799$ & & & \\
Sig. F $=0,000$ & & & \\
Sumber $:$ Data diolah 2017 & &
\end{tabular}

$$
Y=-4,070+0,640 X_{1}+0,488 X_{2}+0,440 X_{3}+e
$$

Nilai konstanta $(\alpha)$ sebesar - 4,070 menunjukkan bahwa apabila Pengalaman auditor $\left(\mathrm{X}_{1}\right)$, tekanan batas waktu audit $\left(\mathrm{X}_{2}\right)$ dan locus of control internal $\left(\mathrm{X}_{3}\right)$ dianggap konstan pada angka 0 (nol), maka variabel skeptisisme profesional auditor adalah sebesar negatif 4,070. Nilai koefisien pengalaman auditor $\left(ß_{1}\right)$ sebesar 0,640. Apabila konstannya variabel lain sementara pengalaman auditor naik sebesar satu satuan, maka skeptisisme profesional auditor akan cenderung meningkat sebesar 0,640 satuan hal itu dikarenakan koefisiensi regresinya yang memiliki nilai positif.

Nilai koefisien tekanan batas waktu audit $\left(ß_{2}\right)$ sebesar 0,488 . Jika konstannya variabel lain dan variabel tekanan batas waktu audit naik sebesar satu satuan, maka skeptisisme profesional auditor akan cenderung meningkat sebesar 0,488 satuan hal itu dikarenakan koefisiensi regresinya yang memiliki nilai positif. Nilai koefisien locus of control internal $\left(\beta_{3}\right)$ sebesar 0,440. Apabila konstannya variabel lain dan 
variabel locus of control internal naik sebesar satu satuan, maka skeptisisme profesional auditor akan cenderung meningkat sebesar 0,440 hal itu dikarenakan koefisiensi regresinya yang memiliki nilai positif.

Digunakannya nilai Adjusted Rsquare untuk mengetahui nilai koefisien determinasi pada model regresi linear moderasi atau model regresi berganda. Dinyatakan Tabel 6, dapat diketahui nilai adjusted $\mathrm{R}^{2}$ adalah 0,799 atau 79,9 persen, yang memiliki arti sebesar 79,9 persen variasi skeptisisme profesional auditor mampu dipengaruhi model yang dibentuk oleh variabel pengalaman auditor $\left(\mathrm{X}_{1}\right)$, tekanan batas waktu audit $\left(\mathrm{X}_{2}\right)$, dan locus of control internal $\left(\mathrm{X}_{3}\right)$ sebesar 79,9\% sedangkan 20,1 persen sisanya dijelaskan oleh variabel lain yang tidak diuji dalam penelitian ini.

Berdasarkan informasi pada Tabel 6 tersebut maka hipotesis pertama $\left(\mathrm{H}_{1}\right)$ dapat diterima, dimana pengalaman auditor berpengaruh positif dan signifikan pada skeptisisme profesional auditor. Semakin tinggipengalaman seorang auditor melaksanakan tugas auditnya, maka skeptisisme profesional auditor semkain meningkat. Berdasarkan teori sikap dan perilaku yaitu perilaku seseorang dapat ditentukan oleh sikap yang terkait hal-hal yang ingin dia lakukan serta terdiri dari keyakinan tentang konsekuensi dari melakukan perilaku, aturan-aturan sosial yang terkait dengan apa yang biasa ia lakukan (kebiasaan). Pengalaman merupakan faktor personal yang dapat membentuk sikap seseorang. Auditor yang memiliki pengalaman yang lebih cenderung tingkat selektifitasnya akan lebih meningkat terhadap informasi yang relevan, oleh karena itu dapat dipengaruhnya seorang auditor agar memiliki sikap skeptiisme profesional auditor. 
ISSN: 2302-8556

E-Jurnal Akuntansi Universitas Udayana Vol.24.3.September (2018):1938-1963

Hasil penelitian ini konsisten yang diteliti oleh Oktaviani (2015), Yanti (2012), dan Attamimi (2015) yang menyatakan pengalaman auditor menunjukkan hubungan positif dan berpengaruh signifikan terhadap skeptisisme profesional auditor, semakin berpengalaman seorang auditor maka akan semakin baik sikap skeptisisme profesional auditornya. Hasil penelitian ini juga sejalan dengan penelitian yang dilakukan oleh Suraida (2005) menunjukkan auditor yang berpengalaman bersikap lebih skeptis. Shaub dan Lawrence (1996) menyatakan semakin banyak pengalaman auditor khususnya lamanya bekerja sebagai auditor semakin tinggi pula tingkat skeptisisme profesional auditor. Tubbs (1992) menyatakan auditor berpengalaman akan cepat mengetahui mengenai kekeliruan atau kecurangan yang tidak lazim, sehingga dapat memberikan penjelasan yang akurat terhadap temuannya.

Berdasarkan informasi pada Tabel 6 hasil uji statistik tersebut maka hipotesis kedua $\left(\mathrm{H}_{2}\right)$ dapat diterima, dinyatakan variabel tekanan batas waktu audit berpengaruh positif signifikan pada skeptisisme profesional auditor. Semakin optimal tekanan batas waktu audit yang diterima oleh auditor, maka akan mendukung auditor untuk meningkatkan sikap skeptisisme profesionalnya.

Dengan demikian bahwa setiap adanya penugasan yang diberikan, seorang auditor telah memiliki manajemen waktu yang disesuaikan dengan banyaknya tugas sehingga auditor harus mampu melaksanakan tugas-tugasnya secara efisien, yaitu menggunakan waktu seoptimal mungkin dalam melakukan penugasan audit laporan keuangan kliennya. Hal tersebut menunjukkan auditor KAP Wilayah Bali menganggap adanya batas waktu audit yang optimal akan mendorong mereka 
melakukan tindakan untuk meningkatkan skeptisisme profesional dalam pelaksanaan audit keuangan perusahaan. Selain itu, apabila tekanan batas waktu terlalu ketat tidak sampai mendorong auditor melakukan perilaku-perilaku yang tidak etis yang bisa mengurangi kualitas pemeriksaan keuangan perusahaan yang dapat mengakibatkan skeptisisme profesional auditor terganggu.

Berdasarkan teori skeptisisme yaitu apabila manusia selalu meragukan (kebenaran) sesuatu, maka disaat bersamaan, Ia akan menemukan sesuatu yang tidak diragukan. Auditor menunjukkan skeptisisme profesionalnya dengan bersikap skeptis atau menunjukkan perilaku meragukan. Tekanan batas waktu dapat berpengaruh terhadap sikap (attitude) auditor (Sweeney, 2003). Pemahaman mengenai teori skeptisisme dapat mengkaji bagaimana adanya batasan waktu penyelesaian audit diharapkan menjadi stimulus sehingga diharapkan auditor merespon tekanan batas waktu audit dengan baik dan termotivasi agar bersikap skeptis pada bukti audit yang diperiksanya.

Hasil penelitian ini konsisten dengan yang diteliti oleh Yanti (2012) yang menemukan bahwa tekanan batas waktu audit berpengaruh positif signifikan terhadap skeptisisme profesional auditor. Sweeney (2003) menyatakan time deadline pressure berpengaruh terhadap sikap auditor dalam pelaksanaan pemeriksaan. Dezort (2002) menyatakan adanya tekanan waktu secara positif dapat meningkatkan identifikasi terhadap hal-hal yang berkaitan dengan kecurangan dalam proses penilaian risiko kecurangan. 
ISSN: 2302-8556

E-Jurnal Akuntansi Universitas Udayana

Vol.24.3.September (2018):1938-1963

Tekanan waktu dapat meningkatkan kemampuan auditor untuk mengidentifikasikan penyimpangan dan salah saji serta membuat penilaian risiko. Syahmina (2016) menemukan bahwa semakin tinggi time deadline pressure yang dirasakan oleh auditor maka dapat berpengaruh terhadap kualitas audit yang dihasilkannya karena waktu optimal tekanan batas waktu audit akan mendukung auditor untuk meningkatkan kualitas audit. Hal ini dapat berdampak pada sikap skeptisisme profesionalnya akan jauh lebih baik.

Berdasarkan tabel 6 hasil uji statistik tersebut maka hipotesis ketiga $\left(\mathrm{H}_{3}\right)$ dapat diterima, yang menyatakan variabel locus of control internal berpengaruh positif dan signifikan pada skeptisisme profesional auditor. Semakin baik locus of control internal auditor, maka semakin tinggi pula skeptisisme profesional yang ditunjukkan oleh auditor. Hal tersebut menunjukkan auditor dengan locus of control internal yang dimiliki akan dengan mudah mengatasi stress dan lingkungan kerja yang lebih tinggi sehingga skeptisisme profesionalnya akan jauh lebih baik. Oleh karena itu individu dengan locus of control internal lebih berorientasii pada keberhasilan karena ia akan beranggapan perilakunya dapat menghasilkan seusatu yang berdampak positif dan juga perilakunya akan cenderung memiliki prestasi tinggi.

Sesuai dengan teori sikap dan perilaku yaitu mampu mempengaruhi faktor personal karena sangat mempengaruhi kepribadian seorang auditor dalam bersikap jujur, teliti, terampil, bertahan meskipun dalam keadaan tertekan serta tidak memihak dalam pemberian opini terhadap laporan keuangan yang diauditnya. Penerapan teori 
sikap dan perilaku dapat digunakan untuk mengkaji bagaimana pengambilan keputusan seseorang akan dipengaruhi oleh sikap seseorang dan sikap seseorang akan dipengaruhi oleh kepribadian seseorang dan individu yakin bahwa dia adalah penentu nasibnya sendiri. Seorang auditor cenderung memiliki locus of control internal, maka dia yakin akan kemampuannya dapat memecahkan masalah, bersikap hati-hatidan auditor tersebut akan mengevaluasi bukti audit dengan detil didukung dengan kemahiran profesionalnya yang cermat dan seksama. Penelitian ini memiliki hasil yang sama dengan hasil yang diteliti oleh Alfa (2013) dan Clark (2011) dinyatakan locus of control internal berpengaruh positif dan signifikan terhadap skeptisisme profesional auditor.

\section{SIMPULAN}

Pembahasan pada latar belakang, landasan teori, metodelogi penelitian dan hasil penelitian, maka dapat disimpulkan bahwapengalaman auditor berpengaruh positif pada skeptisisme profesional auditor, yang memiliki arti semakin tinggi pengalaman seorang auditor dalam melaksanakan tugas auditnya, maka skeptisime profesional auditor semkain meningkat.

Tekanan batas waktu audit berpengaruh positif pada skeptisisme profesional auditor, yang berarti bahwa semakin optimal tekanan batas waktu audit yang diterima oleh auditor, maka akan mendukung auditor untuk meningkatkan sikap skeptisisme profesionalnya. Locus of control internal berpengaruh positif pada skeptisisme profesional auditor, yang berarti bahwa semakin baik locus of control internal auditor, maka semakin tinggi pula skeptisisme profesional yang ditunjukkan oleh auditor. 
ISSN: 2302-8556

E-Jurnal Akuntansi Universitas Udayana Vol.24.3.September (2018):1938-1963

Berdasarkan bahasan hasil penelitian dan simpulan di atas maka saran yang dapat diberikan adalah bagi manajemen KAP diharapkan untuk terus membekali auditor junior dengan pelatihan yang memadai baik eksternal maupun internal, seperti diberikan kesempatan mengikuti seminar, diklat dan memberikan penugasan audit lapangan yang lebih banyak dan variatif, sehingga dapat melaksanakan tugas audit dengan baik serta dapat meningkatkan pengetahuan, keterampilan dan kemampuannya, agar selalu memberikan hasil audit yang berkualitas. Skeptisisme profesional auditor yang diukur dalam penelitian ini adalah khusus berkaitan dengan keuangan perusahaan, sedangkan masih ada jenis audit lainnya yang perlu diketahui skeptisisme profesionalnya, yaitu audit pemerintahan dan audit internal.

Nilai Adjusted Rsquared 0,799 atau 79,9 \% yang memiliki arti variabel yang digunakan penelitian ini hanya dapat menjelaskan skeptisisme profesional auditor sebesar 79,9\%. Dengan demikian masih ada variabel lain yang dapat mempengaruhi skeptisisme profesional auditor. Oleh karena itu, penelitian selanjutnya disarankan agar dapat menambah variabel-variabel lain yang mampu mempengaruhi skeptisisme profesional auditor, seperti penaksiran risiko kecurangan, kompetensi, etika profesii, risiko audit.

\section{REFERENSI}

Alfa, Rosa De Lima Chendy., Indarto, Stefani Lily. 2013. Faktor-Faktor Yang Mempengaruhi Skeptisisme Profesional Auditor Dalam Penugasan Audit. Jurnal Akuntansi Bisnis. Vol.XI No.22. Maret 2013.

Arens, Alvin A., dan James K. Loebbecke, 2012. Auditing An Integrated Approach. Prentice - Hall International, Inc, New York. 
Attamimi, Fikri Muhammad., Riduwan Akhmad. 2015. Faktor-Faktor Yang Mempengaruhi Skeptisisme Profesional Auditor. Jurnal Ilmu \& Riset Akuntansi. Vol. 4 No.7.

BAPEPAM. 1996. Keputusan Ketua BAPEPAM No.Kep-80/PM/1996 bertanggal 17 Januari 1996. Peraturan No. X.K.4 tentang Laporan Realisasi Penggunaan Dana Hasil Penawaran Umum. Jakarta: BAPEPAM.

BAPEPAM. 2003. Keputusan Ketua BAPEPAM No.Kep-36/PM/2003 bertanggal 30 September 2003, Peraturan No. X.K.2 tentang Kewajiban Penyampaian Laporan Keuangan Berkala. Jakarta: BAPEPAM.

Beasly, Mark S., Joseph V, Cardello and Hermason, D.R. 2001. Top 10 Audit Deficiencies.Journal of Accountancy. April. Pp.63-66.

Bonner, S and Lewis, P.C. 1991. Experience is necessary in cue Measurement-A Case Audit Tasks. Contemporer Accounting Research. Fall. Pp. 253-269.

Choo, F. 1995. Auditors Judgement Performance Under Stress: A Test of Predicted Relationship by Three Theoretical Models. Journal of Accounting. Auditing and Finance (Summer); 611-641.

Choo, F. dan K.T. Trotman. 1991. The Relationship Between Knowledge structure and Judgments for Experienced and Inexperienced Auditors. The Accounting Review. Pp:464-485.

Christanti, Made Puspita. 2016. Pengaruh Pengalaman Auditor, Locus Of Control, Pengetahuan Mendeteksi Kekeliruan Pada Audit Judgement (Studi Empiris pada Kantor Akuntan Publik di Bali). Skripsi. Fakultas Ekonomi dan Bisnis. Universitas Udayana.

Clark, et.al. 2011. An Economist`s perspective on the stability of locus of control.

DeZoort, F Todd. 2002. Time Pressure Research in Auditing Implication for Practice. The Auditor`s. Vol.22. University of South Carolina.

Hurt, R.K, Eining, M., and Plumlee, R.D. 2003. Professional Skepticism: A Model with Implication for Research, Practise, and Education. Working Paper, University of Wisconsin-Madison.

Ikatan Akuntansi Indonesia. 2011. Standar Profesional Akuntan Publik, Jakarta: Salemba Empat. 
ISSN: 2302-8556

E-Jurnal Akuntansi Universitas Udayana Vol.24.3.September (2018):1938-1963

Jusup, Al. Haryono. 2014. Auditing (Pengauditan Berbasis ISA). Edisi II. Yogyakarta: Bagian Penerbit Sekolah Tinngi Ilmu Ekonomi YKPN.

Kusnadi, I Made Gheby. 2015. Pengaruh Profesionalisme dan Locus of Control Terhadap Kinerja Auditor di Kantor Akuntan Publik Provinsi Bali. E-jurnal Akuntansi Universitas Udayana. Vol.13. No.1, pp: 276-291.

Libby, R, and Luft, J. 1993. Determinants of Judgement performance in accounting setting: Ability, knowledge, motivation and environment. Accounting Organisations and Society. 18 (5), pp:425-450.

Margheim, Loren, Kelley, Tim., and Pattison, Diane. 2005. An Empirical Anaysis of The Effects of Auditor Time Budget Pressure and Time Deadline Pressure. The Journal of Applied Business Research - Winter. Vol:21. No.1.

Mulyadi. 2008. Sistem akuntansi, Penerbit Salemba Empat, Jakarta.

Noviyanti, Suzy. 2008. Skeptisisme Profesional Auditor Dalam Mendekteksi Kecurangan. Jurnal Akuntansi dan Keuangan Indonesia, Vol.5, No. 1, Juni 2008.

Oktaviani, Nonna Ferlina, Anisykurlillah. 2015. Faktor-Faktor Yang Mempengaruhi Sikap Skeptisisme Profesional Auditor di Kantor Akuntan Publik Kota Semarang. Skripsi. Universitas Negeri Semarang.

Pramudita, Ginda Bella. 2012. Pengaruh Pengalaman Dan Kompetensi Auditor Terhadap Skeptisisme Profesional Auditor Kantor Akuntan Publik (Survei pada 12 KAP di Kota Bandung. Skripsi. Universitas Pasundan.

Retnowati, Reny. 2009. Pengaruh Keahlian auditor, Kompleksitas Tugas dan Locus Of Control Pada Audit Judgment. Skripsi.Universitas Islam Negeri Syarif Hidayatullah, Jakarta.

Robbins, Stephen.P, dan Judge. 2008. Perilaku Organisasi. Buku 2, Jakarta: Salemba Empat.

Robertson, J.C. 2007. Staff Auditor Reporting Decisions under Time Deadline Pressure. Managerial Auditing Journal. Vol.22 No.4 pp: 340-353.

Rotter, J.B. 1966. Generalized expectancies for internal versus external control of reinforcement. Psychological Monographs. 80 (1, Whole No.609). 
Shaub, M.K and Lawrence, J.E. 1996. Ethics, Experience and Professional Skeptiscm: A situastional Analysis. Behavioral Research in Accounting. Vol.8. Supplement. Pp:124-157.

Silalahi, Sem Paulus. 2013. Pengaruh Etika, Kompetensi, Pengalaman Audit Dan Situasi Audit Terhadap Skeptisme Profesional Auditor. Jurnal Ekonomi, Vol.21, No. 3.

Suraida, Ida. 2005.Pengaruh Etika, Kompetensi, Pengalaman Audit Dan Risiko Audit Terhadap Skeptisisme Profesional Auditor Dan Ketepatan Pemberian Opini Akuntan Publik. Sosiohumaniora, Vol. 7, No. 3, November 2005

Sweeney, Breda. 2003. A Qualitative Examination of Management Control System in Large Audit Rirms. Research Seminar. National University of Ireland, Galway.

Syahmina, Fildzah. 2016. Pengaruh Pengalaman, Etika Profesi, Objektifitas Dan Time Deadline Pressure Terhadap Kualitas Audit. Jurnal Ilmu dan Riset Akuntansi. Volume:5. Nomor.4, April 2016.

Tubbs, Richard M. 1992. The Effect of Experience on the Auditor`s Organization and Amount of Knowledge. The Accounting Review (October), pp. 783-801.

Undang-Undang No.8 Tahun 1995 tentang Pasar Modal. www.ojk.go.id. Diakses 2 Februari 2017.

www.iapi.or.id . Daftar Nama KAP di Provinsi Bali. Diakses 29 Januari 2017.

Yanti Frida, Putu. 2012. Skeptisime Profesional Auditor: Kajian Berdasarkan Penilaian Risiko Kecurangan, Pengalaman Auditor dan Tekanan Batas Waktu Audit ( Studi Kasus Pada Auditor BPK RI Perwakilan Provinsi Bali). Tesis. Pascasarjana Akuntansi Fakultas Ekonomi dan Bisnis Universitas Udayana. 